\title{
Fracture zones detection for groundwater exploration integrating Resistivity Profiling and Very Low Frequency electromagnetic methods (Errachidia basin, Morocco)
}

\author{
Youssef AIT BAHAMMOU ${ }^{1, *}$, Ahmed BENAMARA ${ }^{2}$, Abdellah AMMAR $^{1}$, \\ Ibrahim DAKIR ${ }^{3}$ \\ ${ }^{1}$ Mohammed V University, Laboratory of Geophysics and Natural Risks, Faculty of Sciences, \\ Rabat-Agdal, Morocco; e-mail: y.aitbahammou@gmail.com, siadamammar@yahoo.fr \\ ${ }^{2}$ Moulay Ismail University, Laboratory of Applied Geophysics, Faculty of Sciences and \\ Techniques, Errachidia, Morocco; e-mail: benamara13003@gmail.com \\ ${ }^{3}$ Abdelmalek Essaadi University, Faculty of Sciences, Department of Geology, \\ Tetouan, Morocco; e-mail: dakiribrahim@gmail.com
}

\begin{abstract}
Resistivity Profiling and Very Low Frequency (VLF) electromagnetic methods were introduced to study fracture zones detection in Zaouia Jdida locality, within the Errachidia basin. The Horizontal Profiling was conducted in Wenner- $\alpha$ array, with $A B=$ $300 \mathrm{~m}$ and profile lines oriented NW-SE and NE-SW. The resistivity measurements were taken using MAE advanced geophysics instruments. The VLF profiles were implanted with the length reaches $1000 \mathrm{~m}$ and profile lines oriented in NE-SW direction. The VLF measurements were collected using T-VLF iris instrument and the data filtering was done using KHFFILT software. Two filters, Karous-Hjelt and Fraser, were applied to the real component of the secondary electromagnetic field. The qualitative interpretation of resistivity results, showed the presence of subsurface targets; fracture zones were detected at $70 \mathrm{~m}, 240 \mathrm{~m}$ and $450 \mathrm{~m}$ positions along the profile $\mathrm{P} 1$, at $180 \mathrm{~m}, 340 \mathrm{~m}$ and $450 \mathrm{~m}$ positions from the profile P2. The semi-quantitative interpretation of VLF results revealed the presence of two principal fracture zones at L3 and L5 locations, oriented NW-SE, at a depth range of $30 \mathrm{~m}$ to $60 \mathrm{~m}$. The VLF anomaly observed at L3 location is confirmed by the resistivity measurements from the profile $\mathrm{P} 1$ (at $70 \mathrm{~m}$ station). The identified fractures represent the potential zones for groundwater supply and then will have an implication on storage and movement of groundwater in the prospect area.
\end{abstract}

Key words: Errachidia basin, fracture zone, Resistivity, Very Low Frequency, data filtering, groundwater exploration

\footnotetext{
${ }^{*}$ corresponding author
} 


\section{Introduction}

The region of Errachidia-Tafilalt, which includes the study area, faces various environmental difficulties, including the scarcity and salinization of groundwater (Ammary, 2007). In this arid to semi-arid zone, the overexploitation of groundwater, as a result of demographic pressure and agricultural activities, has contributed to the decline in water table levels (Ammary, 2007). Given the scarcity of geophysical studies undertaken in the study area and for the sustainable use of water, it is necessary to implement geophysical investigation methods to better recognize the aquifer systems in the region.

The problematic aimed by this work, is around the potential groundwater within the area of Ain El Atti, in Zaouia Jdida locality. The present paper contributes to evaluate this potential by detecting fracture zones. The fracture zones represent a special target for hydrogeological exploration and can play an important role for groundwater supply and hydrogeological practice (Kirsch, 2006). Generally, fracture zones are considered hydraulic conductors (Kirsch, 2006). To achieve the purpose of this paper, on one hand, the working procedure will be based on the Resistivity Profiling, in order to determine the horizontal variation of resistivity. On the other hand, it will be based on the Very Low Frequency electromagnetic (VLF-EM) technique with the aim of measuring the parameters of the secondary electromagnetic field.

The Horizontal Profiling method was chosen for this study, because it is a common method to measure horizontal variation of electrical resistivity. It has been recognized to be more suitable for hydrogeological exploration of sedimentary basin. Generally, the resistivity method reveals an important result during the detection of fractured zones and metalliferous veins (Dakir et al., 2019). The VLF-EM method is widely used for the detection of buried conductive targets, including aquiferous faulting systems (Ogilvy and Lee, 1991). It offers relatively a fast approach to delineate the fractures (Benson et al., 1997). The advantage of this technique is that the measurements are easy to be interpreted in a qualitative manner (Vargemezis, $2007)$. 


\section{Geography and geological setting}

The study area is located about $50 \mathrm{~km}$ south of Errachidia and $20 \mathrm{~km}$ north of Erfoud (Fig. 1). It is a part of Cretaceous basin of Errachidia (Southeastern Morocco). This basin is characterized by a stratigraphic series that ranges from Paleozoic to Quaternary. In the outcrop (Fig. 1), the basin is generally composed of carbonate deposits of Turonian (Choubert and FaureMuret, 1962), sandstone and sand with gypsum intercalation attributed to Infracenomanian and sand clay with gypsum and anhydrite of Senonian (Choubert, 1948). Locally, from drilling data, the Infracenomanian deposits overlie the Paleozoic (angular discordance). The Quaternary is presented by alluvium and conglomerates. It shows varying thickness layers between 5 and $40 \mathrm{~m}$ (Amharref, 1991).

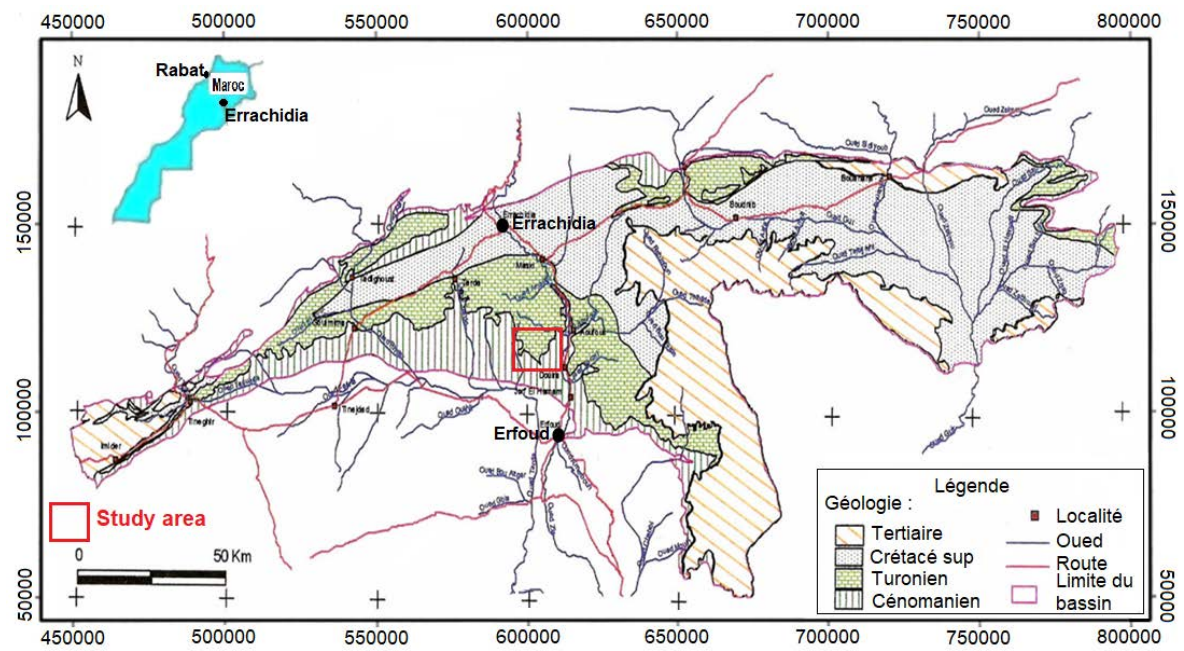

Fig. 1. Geographic situation and regional geology of the study area (DRH-GRZ, 2007) modified.

\section{Hydrogeological data}

The Errachidia basin consists of a multilayer aquifer system consisting of four main aquifer levels (Margat, 1977). The quaternary aquifer, in the south part of the Errachidia basin, is formed by alluvial deposits, which 
contain the essential reserves of the tablecloth. The senonian aquifer, in the north section of the basin, consists of detritic sediments with some sandstone, sand, red marl, gypsum, sodium chloride and limestone. The turonian aquifer consists of fractured limestone and marine origin dolomite as karst facies. Concerning the infracenomanian artesian aquifer, it is made by continental deposits (sandstones and conglomerates) and lagoon sediments (sand, clay and marl). Its water quality varies from one sector to another (Aoubouazza et al., 2013); good quality at the NW of the Ain Al Atti, brackish at Aoufous and highly mineralized between Douira and foundation raft Erfoud (Ammary, 2007) where the residue reaches $16 \mathrm{gL}^{-1}$.

\section{Materials and methods}

\subsection{Resistivity profiling survey}

In Wenner array (Fig. 2), the four electrodes with a definite array spacing "a" are moving after each measurement. In each station, the value of resistivity is affected to the center of the array (Kunetz, 1966). The resistivity of the ground is measured by injected currents and the resulting potential differences at the surface. Two pairs of electrodes are required: electrodes $A$ and $B$ are used for current injections, while electrodes $M$ and $N$ are for potential difference measurements. The apparent resistivity $\rho_{a}$ is calculated from the current $I$ and the potential difference $\Delta V$ (Eq. 1). The coefficient $K$ is called geometric factor. For Wenner configuration, the factor $K$ can be calculated from the electrode spacing Eq. (2):

$\rho_{a}=K \frac{\Delta V_{M N}}{I_{A B}}$,

$K=2 \pi a$.

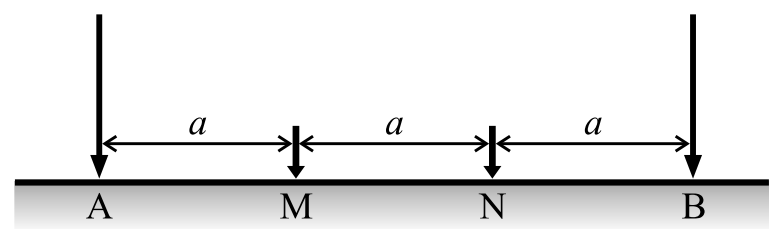

Fig. 2. Wenner configuration used in Resistivity Profiling. 
The instrument used in this research work is MAE advanced geophysics instruments. The measure of the filed resistivity is done by a digital Georesistivimeter (4 iterations). The profiles, oriented in NW-SE and NE-SW directions, were conducted using Wenner- $\alpha$ configuration, where the voltage and the current electrodes are closely spaced and fixed to the center of the array. On the field, Four electric horizontal profiles (P1, P2, P3 and P4) with maximum electrode separation $A B=300 \mathrm{~m}(a=100 \mathrm{~m})$, were carried out. For each profile, 50 measures were taken with a spacing of $10 \mathrm{~m}$.

\subsection{VLF electromagnetic survey}

\subsubsection{Principle and data acquisition}

The Very Low Frequency electromagnetic (VLF-EM) is based on the use of radio waves in the range of 15 to $30 \mathrm{kHz}$ (Müller et al., 1984). The signal (primary magnetic field $H_{p}$ ) emitted by the VLF stations, can be captured in the field by the VLF instruments. When a conductor (e.g. a fracture zone) is crossed by the $H_{p}$ electromagnetic field, an induced current (Current of Foucault) flows through it and produces a secondary magnetic field $H_{s}$ outof-phase with $H_{p}$, oriented in any direction (McNeill and Labson, 1991). In this case, the conductive body acts as a second source (Kaya et al., 2007). The resulting field from the sum of $H_{p}$ and $H_{s}$ is elliptically polarized. This ellipse of polarisation has two components with the same frequency, but different amplitude and phase (Eze et al., 2004). The in-phase $H_{p}$ is the real component $\left(R_{e}\right)$ proportional to the tilt $\tau$ (inclination of the major axis of the ellipse), while the out of phase $H_{p}$ is the imaginary component $\left(I_{m}\right)$ proportional to the ellipticity $\varepsilon$ (the ratio between the minor axis and the major axis $b / a)$. These two components $\tau$ and $\varepsilon$ are described by the equations (3 and 4) below (Saydam, 1981):

$\tau=R_{e} / H_{p}$

$\varepsilon=I_{m} / H_{p}$.

During our study, the survey was carried out using the Receiver T-VLF Iris Instruments, operating in tilt angle mode, in order to measure the parameters of the ellipse of polarization, which are the tilt $\tau$ and the ellipticity $\varepsilon$ (Fig. 3). In this mode, it is convenient to operate with a transmitter (VLF 


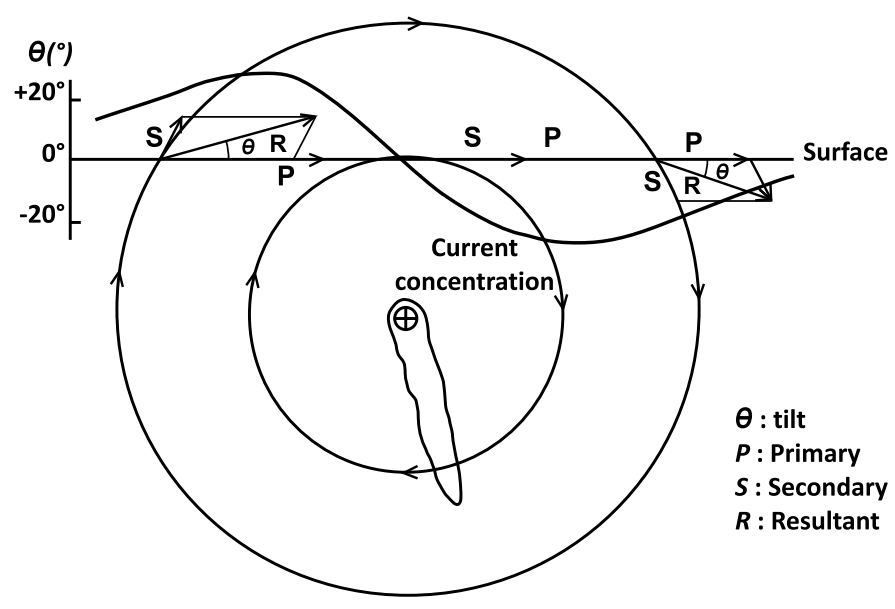

Fig. 3. Principle of induction in a subsurface conductive target and parameters of the ellipse of polarisation in tilt angle mode.

station) which is located in the supposed strike $\left( \pm 45^{\circ}\right)$ of the prospected target for a maximum coupling. For detecting the supposed fractures in the study area, the GBR station located in Rugby (England) has been chosen, with a power of $750 \mathrm{~kW}$, which emits a signal with a frequency of $16 \mathrm{kHz}$. On the fieldwork, five VLF-EM profiles were conducted, with profile length reaches $1000 \mathrm{~m}$. Readings were taken respecting a spacing of $20 \mathrm{~m}$. The profile lines were oriented in NE-SW direction and denoted as L1 to L5.

\subsubsection{Data filtering and semi-quantitative interpretation}

For our measurements, on one hand, the Karous and Hjelt (KH) filter has been applied to the real component. This filter permits the draw of apparent current density cross-sections, which show the response of the conductor in depth (Karous and Hjelt, 1983). Qualitatively, it is possible to discriminate between conductive and resistive structures using apparent current density cross-section (Karous and Hjelt, 1977), where a high positive value corresponds to conductive structure and low negative values are related to resistive one (Benson et al., 1997; Sharma and Baranwal, 2005). On the other hand, the Fraser filter has been applied to the real component too, and the filtered data were presented in the form of a contour map. Therefore, the filtered real component will always show a positive peak above 
an anomalous zone (Fraser, 1969). In order to perform Karous-Hjelt and Fraser filtering on VLF EM data, the software KHFFILT is used in the interpretation of the measurements along VLF traverses.

To better visualize the location of resistivity profiles and VLF lines, the Fig. 4 represents the MNT of the prospect area and the study location.

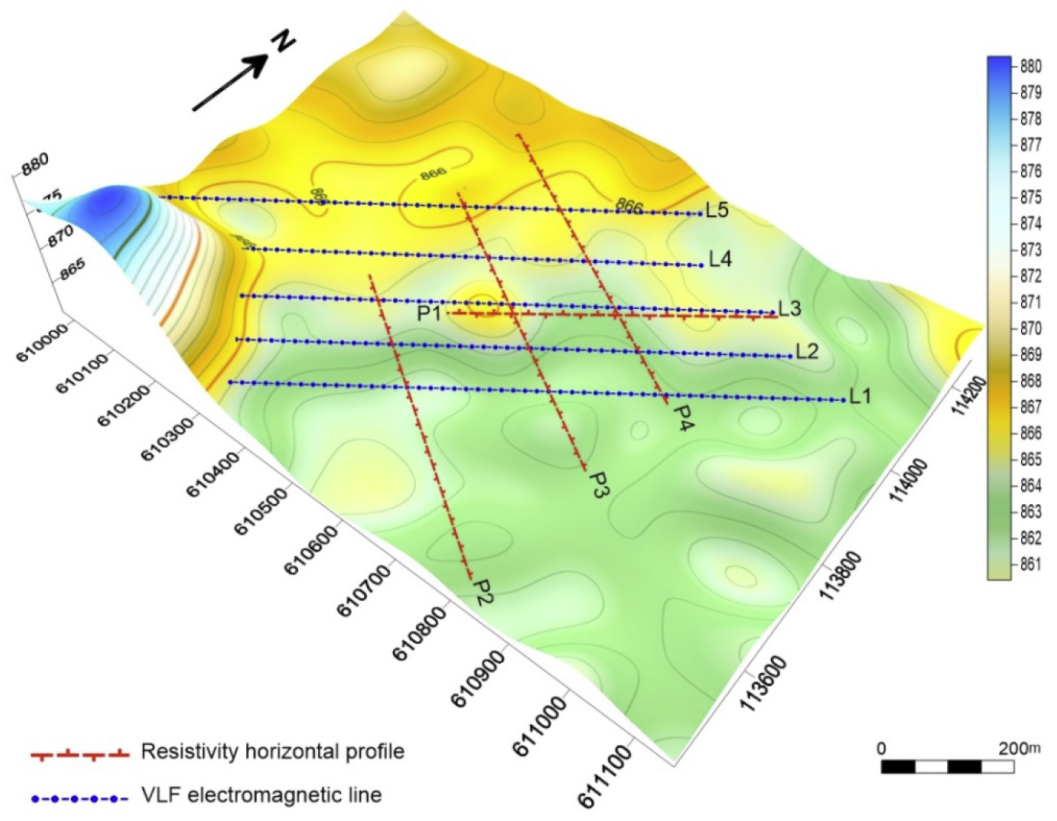

Fig. 4. MNT of the prospect area and study location.

\section{Results and discussion}

\subsection{Resistivity profiling results}

For resistivity data, the measurements were plotted against the distance (Fig. 5). For all electrical profiles, there are fluctuations of apparent resistivity curves, covering a distance of $500 \mathrm{~m}$. From the profile P1 (Fig. 5a), a low apparent resistivity $(46 \Omega \mathrm{m})$ occurs at the beginning of the profile up to a distance of $70 \mathrm{~m}$. Towards NE, two anomalous values of resistivity are observed; the first one $(41 \Omega \mathrm{m})$ is crossed at $240 \mathrm{~m}$ and the second $(45 \Omega \mathrm{m})$ is situated at $450 \mathrm{~m}$. Along the profile P2 (Fig. 5b), from a distance of 


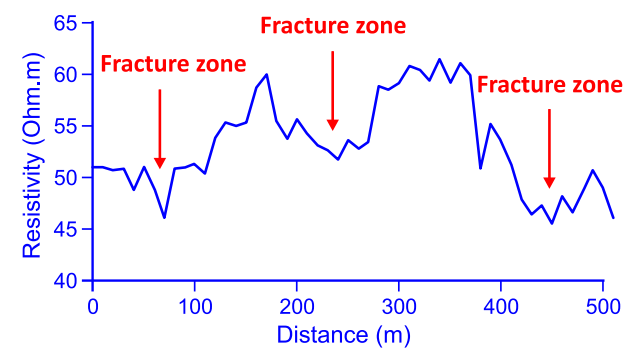

Fig. 5a. The apparent resistivity response against the distance along the profile P1 (NESW) with $A B=300 \mathrm{~m}$.

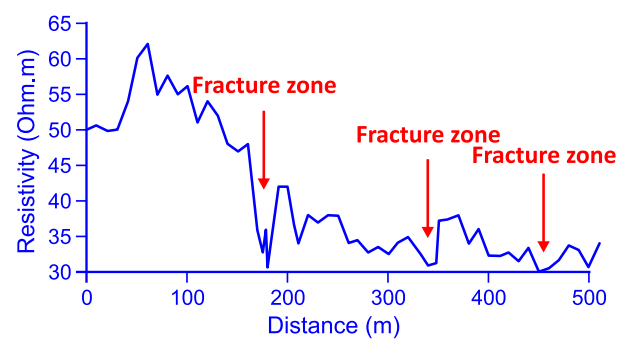

Fig. 5b. The apparent resistivity response against the distance along the profile P2 (NWSE) with $A B=300 \mathrm{~m}$.

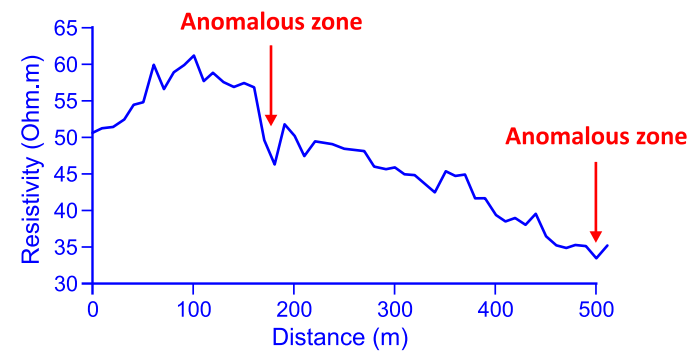

Fig. 5c. The apparent resistivity response against the distance along the profile P3 (NWSE) with $A B=300 \mathrm{~m}$.

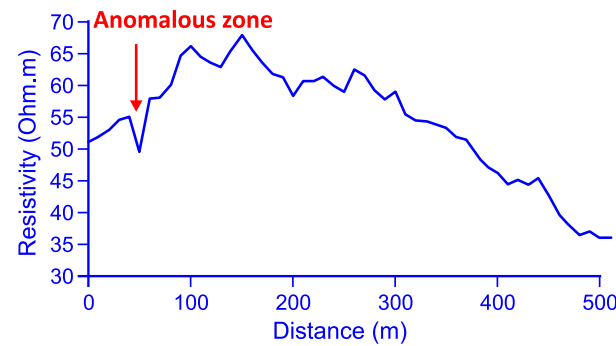

Fig. 5d. The apparent resistivity response against the distance along the profile $\mathrm{P} 4$ (NWSE) with $A B=300 \mathrm{~m}$. 
$60 \mathrm{~m}$ and towards $\mathrm{SE}$, the resistivity decreases from $62 \Omega \mathrm{m}$ to a very low value of $30 \Omega \mathrm{m}$ up to a distance of $450 \mathrm{~m}$. One prominent low resistivity is observed at position $180 \mathrm{~m}(30.6 \Omega \mathrm{m})$, and two other anomalous zones are revealed at $290 \mathrm{~m}$ and $450 \mathrm{~m}$ positions. The profile P3 (Fig. 5c) shows that the resistivity increases from the beginning of the profile and reaches a maximum value of $61 \Omega \mathrm{m}$ at $100 \mathrm{~m}$ position. Towards $\mathrm{SE}$ and for the rest of the profile, the resistivity decreases. One anomalous resistivity value $(46 \Omega \mathrm{m})$ is observed at $180 \mathrm{~m}$ station. From the profile P4 (Fig. $5 \mathrm{~d}$ ), a low apparent resistivity $(49 \Omega \mathrm{m})$ appears at the beginning of the profile up to a distance of $50 \mathrm{~m}$. At range distance between $60 \mathrm{~m}$ and $150 \mathrm{~m}$, the resistivity increases and reaches $67 \Omega \mathrm{m}$ at $150 \mathrm{~m}$ position. From this station $(150 \mathrm{~m})$, the resistivity decreases for the rest of the profile.

The qualitative interpretation of these curves suggests that each low anomalous value of apparent resistivity observed along each profile, indicate the presence of a conductive zone, probably attributed to a fracture zone. Here we evidenced the presence of conductive zones at positions $70 \mathrm{~m}$, $240 \mathrm{~m}$ and $450 \mathrm{~m}$ from $\mathrm{P} 1$, at positions $180 \mathrm{~m}, 340 \mathrm{~m}$ and $450 \mathrm{~m}$ from P2, at position $180 \mathrm{~m}$ on $\mathrm{P} 3$ and at position $50 \mathrm{~m}$ from $\mathrm{P} 4$. Along the profiles P1 and $\mathrm{P} 2$, these conductive zones were easily interpreted as fracture zones.

\subsection{VLF results}

For semi-quantitative interpretation and target visualisation, we focus the analysis on positive Karous-Hjelt and Fraser anomalies. Concerning KH filtered data, the apparent current density cross sections plots were produced. Here, the KH plots are represented for two VLF lines type; L3 and L5. The L3 plot (Fig. 6a) shows prominent positive response between 100-125 m, from the beginning of the profile, corresponding to a conductive axis, resulting in a fracture zone, located between $100-125 \mathrm{~m}$, at a depth extending from $30 \mathrm{~m}$ to $60 \mathrm{~m}$. The L5 plot (Fig. 6b) reveals a positive anomalous related to the presence of a conductive target between $90-120 \mathrm{~m}$, from the beginning of the profile. It is interpreted as a fracture zone at a deep ranging from $20 \mathrm{~m}$ to $60 \mathrm{~m}$. The $\mathrm{KH}$ data filtering from the rest of these lines show no pronounced anomalies. The VLF response is more prominent in L5 location. So, the subsurface target could be more interested in this location. 


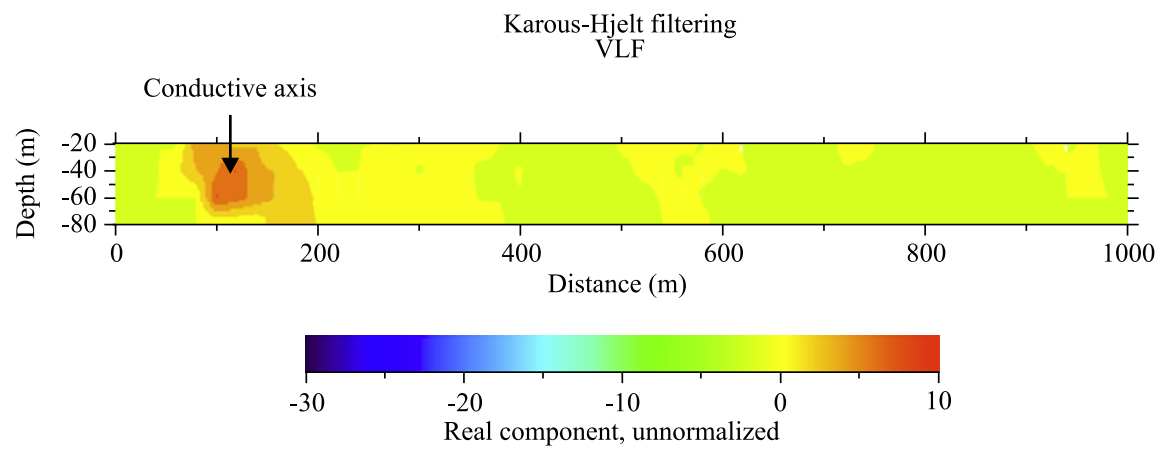

Fig. 6a. Apparent Current density cross section plot of real component data against distance from VLF lines L3 (NE-SW).

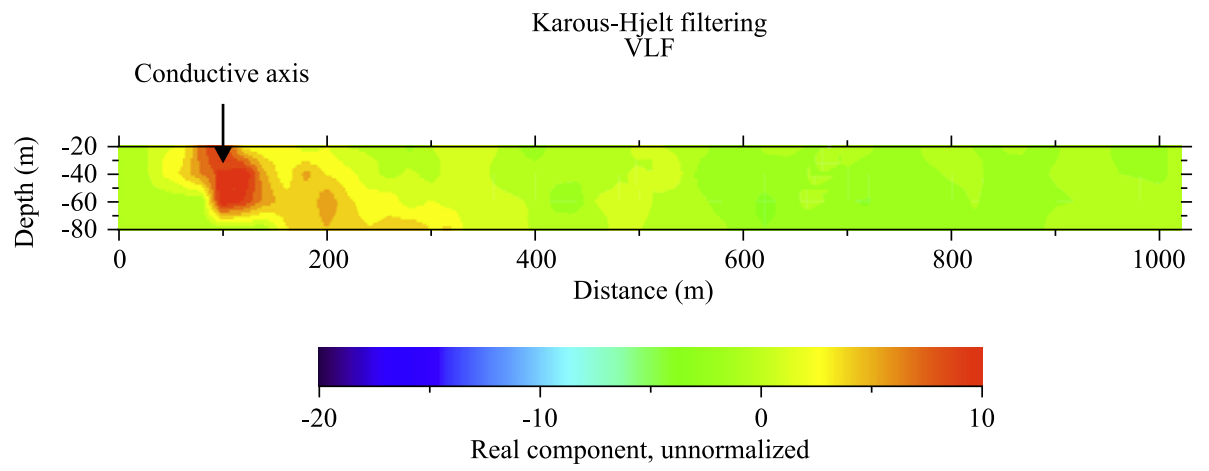

Fig. 6b. Apparent Current density cross section plot of real component data against distance from VLF lines L5 (NE-SW).

The Fraser filtered data are transformed into a contour map (Fig. 7). The Fraser filtered map reveals the presence of anomalies. Two several positive anomalies were distinguished, where the top of the anomalies was observed at L3 and L5 locations. These are related to the presence of conductive structures, interpreted as fracture zones. The low positive Fraser values represent other anomalies, particularly detected at L1 and L5 locations. These are related to other conductive targets, but the VLF response was moderate. Thus, two principal conductive axes oriented NW-SE were identified, which could be the principal fractures in the study area. The rest of anomalies may be associated to secondary conductive axes. 


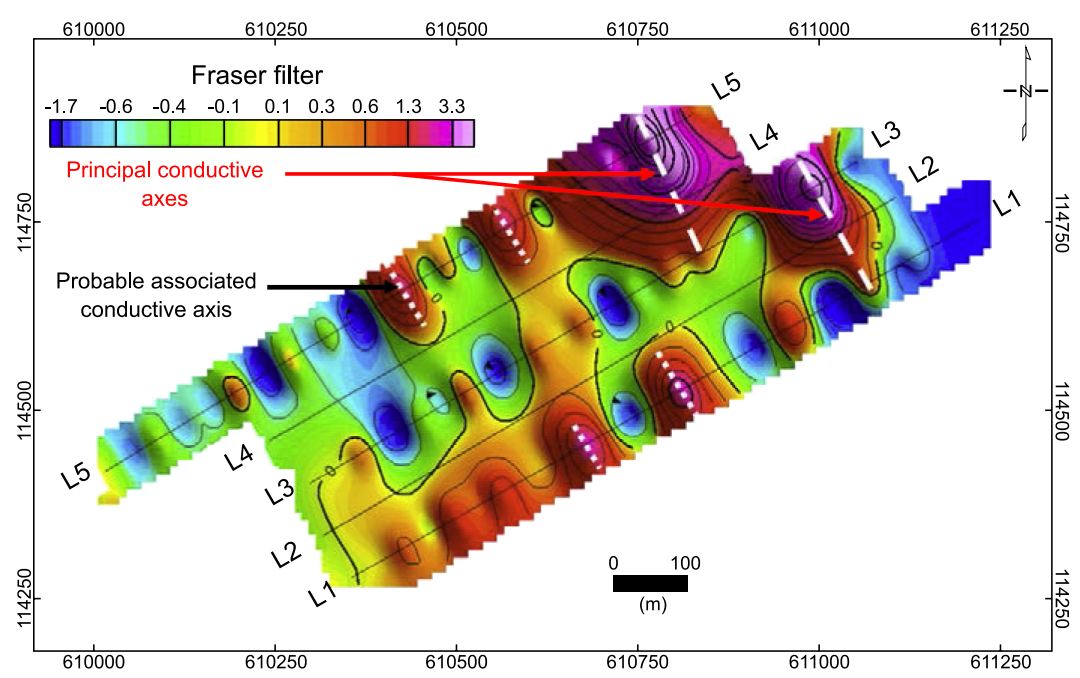

Fig. 7. Interpreted Fraser filtered contour map of real component from five VLF lines.

Taken into account both $\mathrm{KH}$ and Fraser filtered data, a 3D model was elaborated (Fig. 8). The model shows two several anomalies, related to the principal fractures zones oriented in NW-SE direction, at L3 and L5 location. The anomaly observed at L3 location is confirmed by the resistivity

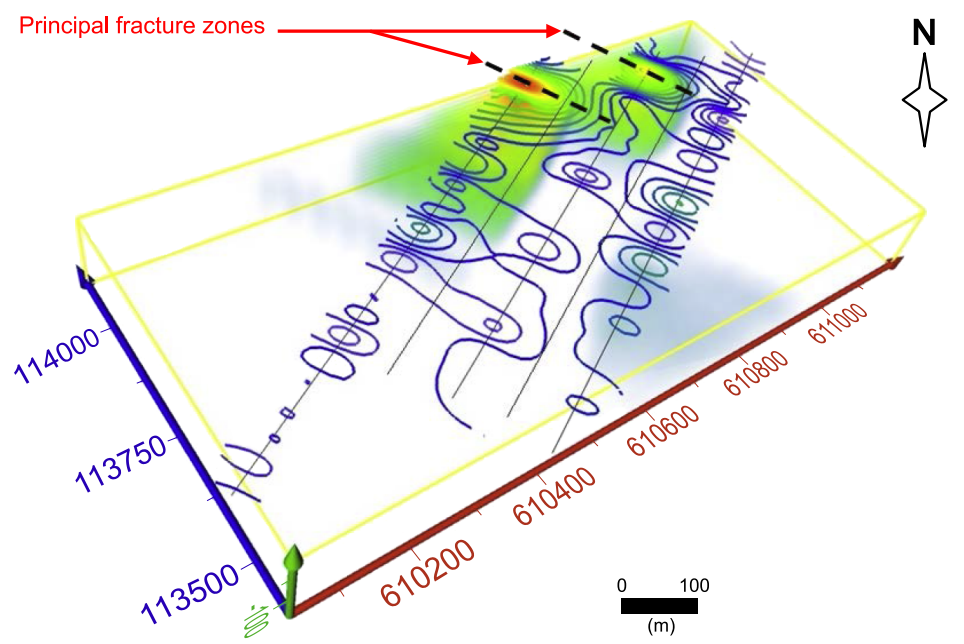

Fig. 8. Interpreted 3D model integrating both Fraser and Karous-Hjelt data filtering. 
measurements along the profile P1 (at $70 \mathrm{~m}$ station). Integrated resistivity and VLF data confirm that the north part of the prospect area is more fractured, because the resistivity response and the VLF anomalies are more pronounced.

\section{Conclusions}

In this study, we contributed to the evaluation of the groundwater potential of Zaouia Jdida locality, by detecting fracture zones. Integrated resistivity results and VLF data confirm the presence of subsurface targets. The resistivity measurements revealed the presence of fracture zones at $70 \mathrm{~m}, 240 \mathrm{~m}$ and $450 \mathrm{~m}$ positions from the profile $\mathrm{P} 1$, at $180 \mathrm{~m}, 340 \mathrm{~m}$ and $450 \mathrm{~m}$ positions along the profile P2. The VLF filtered data showed two several anomalies at L3 and L5 locations, resulting in two principal fracture zones, oriented $\mathrm{NW}-\mathrm{SE}$, at a deep ranging from $30 \mathrm{~m}$ to $60 \mathrm{~m}$. The identified fracture zones constitute the potential zones for hydrogeological practice. Thus, they will have an implication on the movement of groundwater and on its storage in the surveyed area.

Acknowledgements. The authors would like to thank the members of "Agence du Basin Hydraulique d'Errachidia" for the documents made available. Grateful thanks are extended to M. Hritta Driss, Manager of "Société Générale d'Etude et Consult" for the instruments made available. Special thanks are also due to students Ait Bahammou Ismail and Ait Brahim Brahim who helped with the measurements.

\section{References}

Amharref M., 1991: Contribution to the hydrogeological study of the valley of the Ziz: The respective effects of drought and the Hassan Addakhil dam on the downstream water resources (Contribution à l'étude hydrogéologique de la vallée de Ziz. Incidence respective de la sécheresse et du barrage Hassan Addakhil sur les ressources en eau en aval). Thesis, Uni. Besançon, 232 p. (in French).

Ammary B., 2007: Geochemical and isotopic study of the main aquifers of the Cretaceous Basibn of Errachidia and the Tafilalt plain (Etude géochimique et isotopique des principaux aquifčres du bassin Crétacé d'Errachidia et de la plaine de Tafilalt). Thesis, Doc. Uni. Med V Agdal, Rabat, 134 p. (in French). 
Aoubouazza M., Stichler W., Maloszewski P., 2013: Preliminary Interpretation of Environmental Isotope Data in the Ain El Atti Area (Tafilalt). J. Environ. Anal. Toxicol., 3, 2, 170, doi : 10.4172/2161-0525.1000170.

Benson A. K., Payne K. L., Stubben M. A., 1997: Mapping groundwater contamination using DC resistivity and VLF geophysical methods-A case study. Geophysics, 62, 1, 80-86, doi: 10.1190/1.1444148.

Choubert G., 1948: Essay on the paleogeography of Moroccan Mesocretacea (Essai sur la paléogéographie du Mésocrétacé marocain). Volume Jubilaire, Société des Sciences Naturelles du Maroc, 1920-1945, 307-329 (in French).

Choubert G., Faure-Muret A., 1962: Evolution of Moroccan Atlas domain since the Paleozoic times (Evolution de domaine atlasique marocain depuis les temps paléozoïques). In: Durand-Delga M. (Ed.): Livre mémoire P. Fallot, Mém. h. ser. Soc. Géol. France, Paris, 1 447-527 (in French).

Dakir I., Benamara A., Aassoumi H., Ouallali A., Ait Bahammou Y., 2019: Application of Induced Polarization and Resistivity to the Determination of the Location of Metalliferous Veins in the Taroucht and Tabesbaste Areas (Eastern Anti-Atlas, Morocco). Int. J. Geophys., 2019, Article ID: 5849019, 11 p., doi : 10.1155/2019/5849019.

DRH-GRZ (Direction régionale de l'Hydraulique des bassins Versants Guir-Rheris-Ziz), 2007: Hydrogeological synthesis study of cretaceous Errachidia basin (Etude Synthèse hydrogéologique du bassin crétacé d'Errachidia). Report, 44p. (in French).

Eze C. L., Mamah L. I., Israel-Cookey C., 2004: Very low frequency electromagnetic (VLF-EM) response from a lead sulphide lode in the Abakaliki lead/zinc field, Nigeria. Int. J. Appl. Earth Obs., 5, 2, 159-163, doi: 10.1016/j.jag.2004.01.004.

Fraser D. C., 1969: Contouring of VLF-EM data. Geophysics, 34, 6, 958-967, doi : 10.11 90/1.1440065.

Karous M., Hjelt S. E., 1977: Determination of apparent current density from VLF measurements: report. Contribution No. 89, Department of geophysics, University of Oulu., p. 19.

Karous M., Hjelt S. E., 1983: Linear filtering of VLF dip-angle measurements. Geophys. Prosp., 31, 5, 782-794, doi: 10.1111/j.1365-2478.1983.tb01085.x.

Kaya M. A., Özürlan G., Şengül E., 2007: Delineation of soil and groundwater contamination using geophysical methods at a waste disposal site in Çanakkale, Turkey. Environ. Monit. Assess., 135, 1-3, 441-446, doi : 10.1007/s10661-007-9662-x.

Kirsch R., 2006: Groundwater Geophysics - A Tool for Hydrogeology. Springer-Verlag, Berlin Heidelberg, 548 pp., doi : 10.1007/978-3-540-88405-7.

Kunetz G., 1966: Principles of direct current - resistivity prospecting. Geoexploration Monographs, Number 1, Gebr. Borntraeger, Berlin.

Margat J., 1977: Hydrogeological study of the quaternary basin of Tafilalet (Etude hydrogéologique du bassin quaternaire de Tafilalet). Ressources en Eau du Maroc, 310-380 (in French).

McNeill J. D., Labson V. F., 1991: Geological mapping using VLF radio fields. In: Nabighian M. C. (Ed.): Electromagnetic Methods in Applied Geophysics: Volume 2, Application, Parts A and B. Society of Exploration Geophysicists, 521-640, doi : 10. 1190/1.9781560802686. ch7. 
Müller I., Gibert J., Laurent R., 1984: Application of geophysical, electro-magnetic VLF (very low frequency) and micro-seismic methods to the study of the karst of Dorvan Cleyzieu (Southern Jura, France) (Application des méthodes géophysiques, électromagnétiques VLF (Very Low Frequency) et micro-sismique à l'étude du karst de Dorvan Cleyzieu (Jura méridional, France)). Bulletin du Centre d'hydrogologie, 5, 3, Université de Neuchâtel, Centre d'hydrogéologie, 145-162 (in French).

Ogilvy R. D., Lee A. C., 1991: Interpretation of VLF-EM in-phase data using current density pseudosections. Geophys. Prospect., 39, 4, 567-580, doi : 10.1111/j.1365-24 78.1991.tb00328.x.

Saydam A. S., 1981: Very low frequency electromagnetic interpretation using tilt angle and ellipticity measurements. Geophysics, 46, 11, 1594-1605, doi: 10.1190/1.144 1166.

Sharma S. P., Baranwal V. C., 2005: Delineation of groundwater-bearing fracture zones in a hard rock area integrating very low frequency electromagnetic and resistivity data. J. Appl. Geophys., 57, 2, 155-166, doi: 10.1016/j.jappgeo.2004.10.003.

Vargemezis G., 2007: Interpretation of VLF measurements related to hydrogeological surveys. Bulletin of the Geological Society of Greece, 40, 2, 593-604, doi: 10.12681/ bgsg. 16340 . 